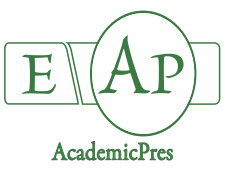

Bartieres EMM et al. (2020)

Notulae Botanicae Horti Agrobotanici Cluj-Napoca 48(1):234-244

DOI: $10.15835 /$ nbha 48111720

Research Article

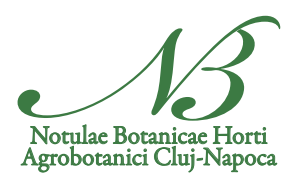

\title{
Shading as a means of mitigating water deficit in seedlings of Campomanesia xanthocarpa (Mart.) O. Berg
}

\author{
Edinéia M.M. BARTIERES ${ }^{1}$, Silvana P.Q. SCALON ${ }^{2 *}$, \\ Daiane M. DRESCH${ }^{2}$, Edvânia A.S. CARDOSO², \\ Mailson V. JESUS ${ }^{2}$, Zefa V. PEREIRA ${ }^{1}$ \\ ${ }^{1}$ Federal University of Grande Dourados, Faculty of Biological and Environmental Sciences, Road Dourados-Itahum, \\ Km 12, Rural Subdivision, CEP: 79804970, Dourados, State Mato Grosso do Sul, \\ Brazil; estudanteacinatob8305@hotmail.com; zefapereira@ufgd.edu.br \\ ${ }^{2}$ Federal University of Grande Dourados, Faculty of Agricultural Sciences, Road Dourados-Itabum, Km 12, Rural Subdivision, CEP: \\ 79804970,Dourados, State Mato Grosso do Sul,Brazil; daiamugnol@hotmail.com; edvania_apcardoso@hotmail.com; \\ mvjagro@gmail.com; silvanascalon@ufgd.edu.br ('correspondingauthor)
}

\begin{abstract}
In this research it was hypothesized that Campomanesia xanthocarpa can overcome some level of water deficiency by adjusting physiological parameters and that shading minimizes the water deficit effects while maintaining elevated photosynthetic rates and relative water content of the leaves and makes a resumption of metabolism and growth when the water supply is normalized. The seedlings were submitted to two water regimes (continuous irrigation - CI and intermittent irrigation - II), three shading percentages (0, 30 and 70\%) and six evaluation times (Start - T0, $1^{\text {st }}$ Photosynthesis Zero $-1^{\text {st }}$ P0, $1^{\text {st }}$ Recovery - $1^{\text {st }}$ REC, $2^{\text {nd }}$ Photosynthesis Zero $-2^{\text {nd }} P 0,2^{\text {nd }}$ Recovery $-2^{\text {nd }} R E C$ and END). Plants under water deficit at $0 \%$ shading led to a reduction in photosynthetic metabolism, relative water content (RWC), leaf area, number of leaves, and height, especially during the stress periods $1^{\text {st }}$ and $2^{\text {nd }} \mathrm{P} 0$. The 30 and $70 \%$ shading mitigated the stressful effect of water deficit on $C$. xanthocarpa seedlings. The results did not confirm the hypothesis that $C$. xanthocarpa seedlings are intolerant to water deficit since, although sensitive, they presented a potential for recovery of photosynthetic and growth characteristics under all cultivation conditions. It was concluded that that shading minimizes the stressful effects of water deficit.
\end{abstract}

Keywords: abiotic stress; guabiroba; shading; photosynthetic metabolism

Abbreviations: A: photosynthetic rates; A/Ci: rubisco carboxylation efficiency; ATP: adenosine triphosphate; CI: continuous irrigation; END: end of the experiment; II: intermittent irrigation; IRGA: infrared gas analyzer; gs: stomatal conductance; LA: leaf area; NL: number of leaves; T0: time zero - start; P0: Photosynthesis next zero; REC: recovery; RH: relative humidity; RWC: relative water content; SI: stomatal index; SO: stomatal opening.

\section{Introduction}

Many studies on native species searching for information on the production of seedlings for reforestation in areas subject to water deficit and different levels of shading, consider physiological responses 
such as gas exchanges that these species present (Flexas et al., 2012; Dos Anjos et al., 2015; Junglos et al., 2016; Pena-Rojas et al., 2018).

Holmgren et al. (2012) noted in their review that in various ecosystems plants are exposed to water and thermal stress, however, shading can improve plant survival and growth as it reduces air and leaf temperature and leaves and transpiration. The higher light incidence raises the ambient temperature and may also increase the vapor pressure deficit. These conditions when associated with water deficit result in stomatal closure and consequently lower $\mathrm{CO}_{2}$ uptake and lower photosynthetic rate (Favaretto et al., 2011).

Species that can make adjustments to leaf characteristics have high photosynthetic plasticity for acclimatization to light, which favors the maintenance or increase of carbon assimilation when subjected to variations in the luminous environment (Dos Anjos et al., 2015).

For most plants, conditions of low soil water availability, affect several metabolic processes, such as stomatal closure; the reduction of stomatal conductance, photosynthesis and transpiration; reduction of leaf area development; and a reduction in yield and translocation of photoassimilates, leading to growth rate decline (Scalon et al., 2011; Tonello and Teixeira Filho, 2018). These conditions lead to a compromise in enzymatic activity, especially the activity of enzymes responsible for fixation and assimilation of carbon gas and ATP synthesis; the activity of antioxidant enzymes is also compromised (Campelo et al., 2015).

Some plants when subjected to water deficit reach photosynthetic recovery when submitted to mild to moderate stress followed by normal water supply, provided they possess physiological mechanisms of tolerance to dehydration, such as osmotic or elastic adjustment. Other plants under severe stress, recover slowly or almost not at all (Rosa et al., 2017).

Campomanesia xanthocarpa (Mart.) O. Berg (Myrtaceae), popularly known as "guabiroba" (Luber et al., 2017) has a wide geographical distribution, being present in the south of Brazil and distributed through Argentina, Bolívia, Paraguay, and Uruguay. C. xanthocarpa is commonly found in forests with soils high in organic matter (Soares-Silva et al., 1998; Souza et al., 2017) it is also highly attractive to dispersing fauna. The leaf, fruit, bark, wood, and stem all have considerable potential for commercial and medicinal exploitation, being used to treat various diseases, such as reducing blood cholesterol levels in hypercholesterolemia (Klafke et al., 2010). However, little is known about the metabolism associated with water and light stress in the development of this species.

Taking into account the above facts, this work tested the hypotheses that C. xanthocarpa can overcome some level of water deficiency by adjusting physiological parameters related to leaf anatomy, stomatic conductance, and photosynthesis. Also, we hypothesize that shading minimizes the water deficit effects while maintaining elevated photosynthetic rates and relative water content of the leaves and makes a resumption of metabolism and growth when the water supply is normalized.

Hence, the objective of this work was to evaluate the potential of shading in mitigating water stress in C. xanthocarpa seedlings submitted to water deficit intermittent and the recovery potential after interruption of stressful conditions.

\section{Materials and Methods}

\section{Plant and cultivation material}

The present study was carried out in the nursery of the Faculty of Agrarian Sciences at the Federal University of Grande Dourados (UFGD), in the municipality of Dourados, situated in the state of Mato Grosso do Sul.

Campomanesia xanthocarpa seedlings with $15 \mathrm{~cm}$ height were cultivated in pots with a capacity of $8 \mathrm{~kg}$ containing Dystroferric Red Latosol and sand (1:1 v:v) and left to acclimatize for 20 days. Each experimental unit consisted of a vessel containing two seedlings. 
The experiment was conducted in a place covered with either no shading plastic or plastic covered with a black nylon screen known as sombrite to simulate shading of $30 \%$ and $70 \%$. Considering that the natural environmental conditions present different luminous availabilities, with variations in temperature and relative humidity $(\mathrm{RH})$, the present work controlled only the shading of the cultivation environments of the seedlings, and the temperatures and RH oscillated according to climatic conditions in the experimental period.

Under each shade level the seedlings were divided into two blocks, the first one with continuous irrigation and the second with intermittent irrigation, totaling 48 seedlings per shade level.

The evaluations were performed at the beginning of the experimental period (Start - T0) and the others when verified in any of the treatments, a condition of photosynthesis close to zero $\left(1^{\text {st }}\right.$ and $\left.2^{\text {nd }} \mathrm{P} 0\right)$ and zero photosynthesis recovery in at least one of the treatments $\left(1^{\text {st }}\right.$ and $2^{\text {nd }}$ REC) and the last evaluation characterized as the END.

During the experiment, control plants (CI) were periodically irrigated to maintain seventy percent of substrate water retention capacity (70\% RWC). For the plants under intermittent irrigation (II) characterized by stress, irrigation was suspended until the photosynthetic rate presented levels close to zero, when the seedlings were again submitted to daily water supply, the substrate water retention capacity was maintained at $70 \%$, until the photosynthetic rate reached at least $80 \%$ of the control value at the same level of shading. A further irrigation suspension cycle was performed, and the seedlings evaluated up to 45 days after the second recovery and the experiment was completed at 106 days.

\section{Evaluations}

The relative water content (RWC) in four leaves was determined after each period of evaluations, according to the mathematical expression: RWC $=100$ (fresh mass - dry mass) / (saturated mass - dry mass)]. The leaves were collected at 7 hours and taken to the laboratory, later cut with cylinders of known area. After weighing the fresh mass, they were placed in petri dishes with distilled water for $24 \mathrm{~h}$ for saturation. After weighing the saturated disks were dried to determine dry mass.

The infrared gas analyzer (IRGA) brand ADC, model LCi PRO was used for the assessments of photosynthetic rates $(A)$, stomatal conductance $(g s)$ and rubisco carboxylation efficiency $(A / C i)$. The evaluations were carried out on four seedlings from each shade level, two seedlings with continuous irrigation and two with intermittent irrigation. The readings were taken in the morning between 8 and 11 hours, on the same previously marked leaves from the beginning to the end of the experiment. The leaves evaluated were mature intermediate leaves of similar age at the same position on the stem of the two plants from each trial group of identical shade/water level.

The leaf number per plant was noted, the leaf area assessed using a leaf area integrator LI-COR model LI-3100C and root length and height was measured with the aid of a ruler. Two plants from each trial group were evaluated. The stomatal opening ( $\mathrm{SO}$ ) was determined from paradermic impressions prepared in the morning, between eight and eleven o'clock, with Super Bonder glue samples from the limbus medial region of the leaves on the adaxial and abaxial surfaces. The stomatal index (SI) was calculated using the formula proposed by Salisbury (1927).

\section{Experimental design and statistical analysis}

The experiment was conducted in a completely randomized design in a factorial scheme $3 \times 2 \times 6$, with three levels of shading $(0,30$ and $70 \%)$, two irrigation conditions (continuous irrigation - CI and intermittent irrigation - II) and six evaluation periods, Start -T0, $1^{\text {st }}$ Photosynthesis Zero $-1^{\text {st }} \mathrm{PO}, 1^{\text {st }}$ Recovery $-1^{\text {st }} \mathrm{REC}, 2^{\text {nd }}$ Photosynthesis Zero $-2^{\text {nd }} P 0,2^{\text {nd }}$ Recovery $-2^{\text {nd }}$ REC and END), with three repetitions. The data were submitted to analysis of variance and the significant effects of the means of shading were compared by the Tukey test. The experimental periods were evaluated using the test Scott Knott and the irrigation conditions by the Bonferroni T-test, all at 5\% probability. 
The photosynthetic parameters were analyzed only in the experimental periods using the Scott Knott test and plotted in conjunction with the relative water content data. Statistical analysis SISVAR 5.3 (Ferreira, 2010) was used to analyze the results.

\section{Results}

\section{Gas exchange}

The photosynthetic rate $(A)$ was lower in the seedlings under intermittent irrigation (II) at 0 and 30\% shading in the $1^{\text {st }}$ and $2^{\text {nd }} \mathrm{P} 0$ at 13 and 44 days (Figure $1 \mathrm{~A}$ ). The seedlings recovered in the 1 st and 2 nd Recovery at 25 and 52 days by the established criterion of $80 \%$ of the control value.


Figure 1. Photosynthetic rates $\left(A-\mu \mathrm{mol} \mathrm{m}^{-2} \mathrm{~s}^{-1}\right)(\mathrm{A}, \mathrm{B}, \mathrm{C})$, stomatal conductance $\left(g s-\mathrm{mol} \mathrm{m}^{-2} \mathrm{~s}^{-1}\right)(\mathrm{D}, \mathrm{E})$ and rubisco carboxylation efficiency $\left(A / C i-\mu \mathrm{mol} \mathrm{m}^{-2} \mathrm{~s}^{-1} \mu \mathrm{mol}^{-1} \mathrm{H}_{2} \mathrm{O}\right)(\mathrm{F}, \mathrm{G})$ of Campomanesia xanthocarpa seedlings as function of continuous irrigation (CI) and intermittent (II) conditions, shading $(0,30$, and $70 \%$ ) and experimental periods (Start: T0, $1^{\text {st }}$ and $2^{\text {nd }}$ Photosynthesis Zero: P0, $1^{\text {st }}$ and $2^{\text {nd }}$ Recovery: REC and END). Lowercase letters compare the same shading and experimental period in the different irrigation conditions. Uppercase letters compare the same irrigation conditions in the different shading and experimental period

The $A$ was lower in the seedlings under II independent do shading (Figure 1B). Under II, $A$ was lower in the $1^{\text {st }}$ and $2^{\text {nd }} \mathrm{P} 0$, and after suspension of irrigation, however, after the second suspension of the suspension and maintained by a lower plant control (CI) (Figure 1B, C). 
For stomatal conductance $(g s)$, the seedlings under II and light extremes evaluated (0\% and $70 \%)$ presented the lowest values and reduction in the most severe fall in the $2^{\text {nd }} \mathrm{P} 0$ and without recovery in the seedlings under II (Figure 1D, E).

The efficiency of the carboxylation of rubisco $(A / C i)$ was lower in the plants under water deficit (II) and $0 \%$ of shading. The reduction was more significant from the $1^{\text {st }} \mathrm{P} 0$, whose values were later recovered, however, after the second irrigation suspension the seedlings took longer to recover, although at the end of the evaluations the $A / C i$ values did not vary significantly from the control plants $(\mathrm{CI}$ ) (Figure 1F, G).

\section{Relative water content}

The relative water content (RWC) was lower under $0 \%$ shade independent of water regime and water deficit (II) by 30\% shade (Figure 2A). Under water deficit the shaded seedlings maintained higher RWC than the seedlings under $0 \%$, suggesting that shading mitigated water deficit in the seedlings (Figure 2B). It is also observed that, with II, RWC reduced significantly in the $1^{\text {st }}$ and $2^{\text {nd }} \mathrm{P} 0$ and the values were not retrieved at the end of the evaluations.


Figure 2. Relative water content (RWC\%) of Campomanesia xanthocarpa seedlings as function of continuous irrigation (CI) and intermittent (II) conditions, shading (0,30, and 70\%) and experimental periods (Start: T0, $1^{\text {st }}$ and $2^{\text {nd }}$ Photosynthesis Zero: P0, $1^{\text {st }}$ and $2^{\text {nd }}$ Recovery: REC and END). Lowercase letters compare the same shading and experimental period in the different irrigation conditions. Uppercase letters compare the same irrigation conditions in the different shading and experimental period

In both the $1^{\text {st }} \mathrm{P} 0$ and the $2^{\text {nd }} \mathrm{P} 0$, the seedlings under I) and $0 \%$ of shading presented photosynthesis close to zero with RWC of the leaves around 56\%. However, shaded seedlings maintained higher averages of $A$ with RWC around 76 to $80 \%$ (Figure 3). Similar behavior was observed for stomatal conductance $(g s)$ and carboxylation efficiency of Rubisco $(A / C i)$. The shaded seedlings presented lower percentages of reduction of some parameters involved in the production of photoassimilates when compared to the seedlings cultivated at $0 \%$ shading

\section{Growth characteristics}

The leaf area increased in the seedlings under shading $70 \%$ and during the evaluation periods, and from $2^{\text {nd }} \mathrm{P0}$ (Figure 4A) the seedlings under II showed a high leaf area (Figure 4A, B). The number of leaves was lower in seedlings under shading $30 \%$ and CI, however, did not vary under II, at the end of the evaluations, seedlings showed a significant increase in the number of leaves (Figure 4C, D).

The roots were longer in the seedlings under II and shading $0 \%$ (Figure $5 \mathrm{~A}$ ) and in both $1^{\text {st }}$ and $2^{\text {nd }} \mathrm{P} 0$ (Figure 5B). Seedling height did not vary between the shades in II, but was less than $70 \%$ of shading when compared to seedling control (IC) (Figure 5C, D). At the end of the evaluations as seedlings did not present differences in the height between the irrigation forms. 


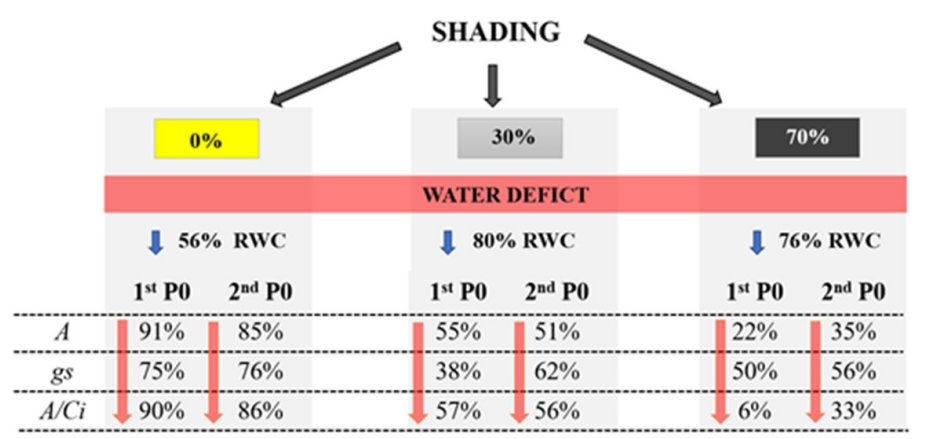

Figure 3. Representation of the effect of shading $(0,30$, and $70 \%)$ on the percentage of reduction of photosynthetic parameters (photosynthetic rate - $A$, stomatal conductance - $g$ s and carboxylation efficiency of Rubisco $-A / C i$ ) in function of relative water content (RWC \%) in the leaves of Campomanesia xanthocarpa seedlings under deficit intermittent (II) water compared to continuous irrigation (CI)
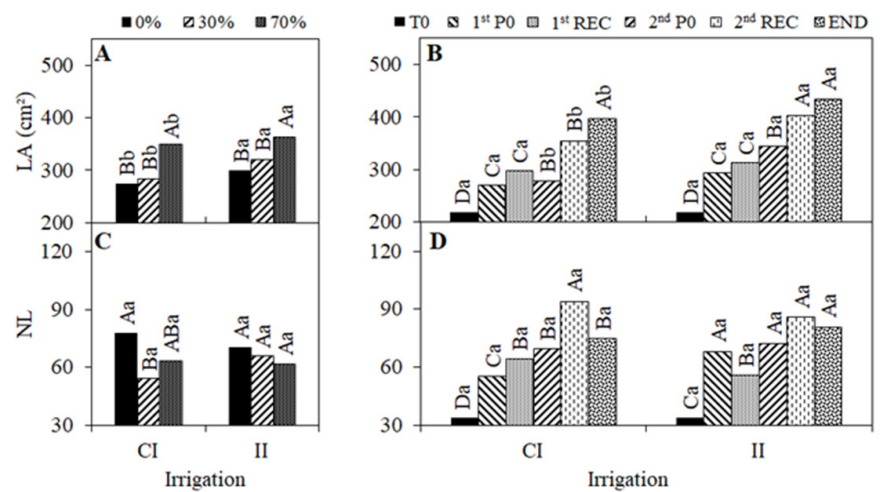

Figure 4. Leaf area - LA $\left(\mathrm{cm}^{2}\right)(\mathrm{A}, \mathrm{B})$ and number of leaves - NL (C, D) of Campomanesia xanthocarpa seedlings as function of continuous irrigation (CI) and intermittent (II) conditions, shading (0,30, and $70 \%$ ) and experimental periods (Start: T0, $1^{\text {st }}$ and $2^{\text {nd }}$ Photosynthesis Zero: P0, $1^{\text {st }}$ and $2^{\text {nd }}$ Recovery: REC and END). Lowercase letters compare the same shading and experimental period in the different irrigation conditions. Uppercase letters compare the same irrigation conditions in the different shading and experimental period


Figure 5. Root length - $\mathrm{cm}(\mathrm{A}, \mathrm{B})$ height $-\mathrm{cm}(\mathrm{C}, \mathrm{D})$ of Campomanesia xanthocarpa seedlings as function of continuous irrigation (CI) and intermittent (II) conditions, shading (0,30, and 70\%) and experimental periods (Start: T0, $1^{\text {st }}$ and $2^{\text {nd }}$ Photosynthesis Zero: P0, $1^{\text {st }}$ and $2^{\text {nd }}$ Recovery: REC and END). Lowercase letters compare the same shading and experimental period in the different irrigation conditions. Uppercase letters compare the same irrigation conditions in the different shading and experimental period 


\section{Stomatal characterists}

Shading provided greater stomatal opening (SO) of seedlings under II, however, we emphasize that there was no variation in opening between irrigation forms (Figure 6A). SO reduced only at $2^{\text {nd }} \mathrm{P0}$ in seedlings under intermittent irrigation, but increased significantly after normal water supply ( $2^{\text {nd }}$ REC) (Figure 6B).

The stomatal index (SI) was smaller in seedlings under $70 \%$ shade regardless of irrigation form (Figure 6C), and decreased during the evaluation periods, however, this reduction was smaller in seedlings under II (Figure 6D).
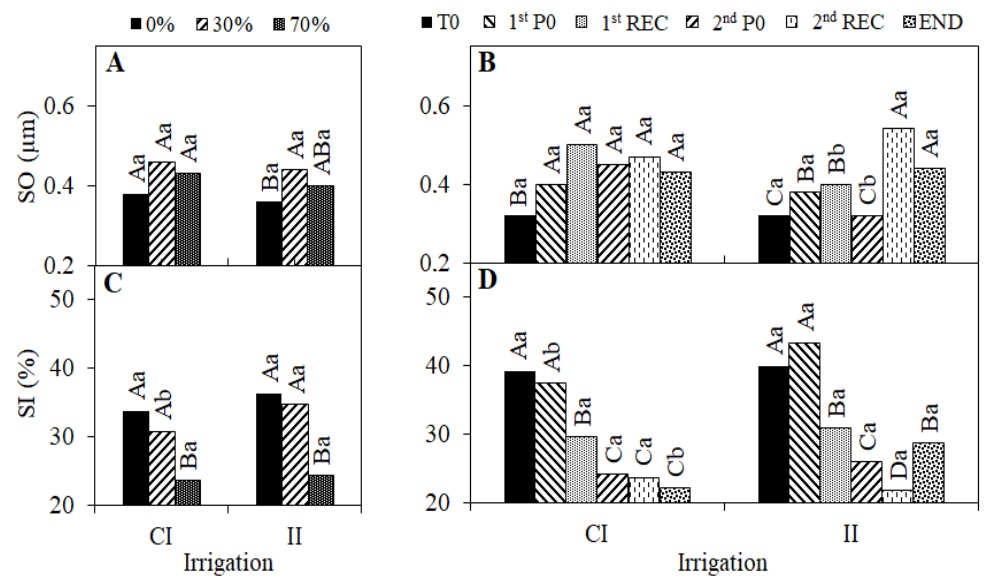

Figure 6. Stomatal opening - SO $\mu \mathrm{m}(\mathrm{A}, \mathrm{B})$ and stomatal index - SI (\%) (C, D) of Campomanesia xanthocarpa seedlings as function of continuous irrigation (CI) and intermittent (II) conditions, shading $(0,30$, and $70 \%)$ and experimental periods (Start: T0, $1^{\text {st }}$ and $2^{\text {nd }}$ Photosynthesis Zero: P0, $1^{\text {st }}$ and $2^{\text {nd }}$ Recovery: REC and END). Lowercase letters compare the same shading and experimental period in the different irrigation conditions. Uppercase letters compare the same irrigation conditions in the different shading and experimental period

\section{Discussion}

The seedlings of Campomanesia xanthocarpa submitted to intermittent irrigation showed lower RWC in the leaves, reduction in the parameters implied in the production of photoassimilates, however, it did not record any impairment in shoot growth.

The photosynthetic parameters such as $A, g s$ and $A / C i$ reduced by II. However, we observed that the shading minimized this reduction as shown in Figure 3. In addition, the shading also kept high the RWC. The behavior of these parameters evidences the mitigating effect of the shading on the water deficit. It is interesting to note that the seedlings took 12 days to recover the photosynthetic rate of the first cycle of irrigation suspension and only 8 days in the second cycle, suggesting the possibility of memory or stress mark in this species as reported in the literature. These markers are genetic or biochemical modifications triggered after a previous stressful condition that cause faster responses to a recurrent stressful event, enabling species to acclimate (Bruce et al., 2007; Walter et al., 2011).

The effect of shading of $30 \%$ and $70 \%$ reflected in foliar tissues of C. xanthocarpa, helped in hydration, maintenance of the integrity of the water transport system and development of water potential. When the soil is in the process of a progressive loss of moisture shading minimized water loss of vegetative tissues, in the face of this water deficit. In another study, C. xanthocarpa seedlings with water deficit and $40 \%$ shading showed reduction of all photosynthetic metabolism characteristics when subjected to intermittent irrigation, but at 109 days of the experiment, the recovery of these characteristics after irrigation was resumed (Bento et al., 2016) 
These results show that shading positively interfered in the photosynthetic rate of seedlings in a water deficit condition, the results also showed a trend of higher photosynthesis under the shade of $70 \%$ in CI conditions. By mimicking conditions found in nature, these different light conditions interfere with photosynthesis, chlorophyll synthesis and physiological aspects of plants (Azevedo et al., 2015), besides reducing ambient temperature (Holmgren et al., 2012)

Greater accessibility of water, and solar radiation favor greater stomatal opening, which cuts down the diffusion resistance of $\mathrm{CO}_{2}$ and contributes to maintaining higher photosynthetic rates (Flexas et al., 2012) resulting in higher growth and biomass accumulation (Fan et al., 2015). However, in our study the plants under II did not show growth reduction when compared to the control (CI), even with lower RWC, $g s$ and $A$, behavior that may suggest the plasticity of this species in this growing condition.

We observed in this work that the variations in stomatal conductance of C. xanthocarpa reflected the variations in soil moisture as a function of irrigation. In most species, reductions in stomatal conductance associated with stomatal closure, reduce water loss when exposed to conditions of low water availability and high insolation (Campelo et al., 2015). It is interesting to note that under $30 \%$ shading there was no difference in $g s$ and SO between the two irrigation regimes, suggesting that in this condition the species can express mechanisms of adaptation to the stressful condition.

Myracrodruon urundeuva Fr. All., a generalist habitat species observed in several phytophysiognomies, when subjected to water stress at low levels of light, also presents a reduction of transpiration and stomatal conductance, and consequently slows its development (Queiroz et al., 2002). We emphasize that the seedlings of C. xanthocarpa under II showed a reduction in $g s$ under $0 \%$ shading, which reflected in a lower leaf area, but higher root growth was observed, not varying the height and number of leaves.

In water deficit conditions there is a greater root expansion, due to moisture loss to the soil surface, which triggers the synthesis of abscisic acid in the roots, stimulating growth, and when the acid is transported to different parts of the plant, it triggers responses such as suppression of leaf growth and abscission, as well as stomatal closure (Taiz et al., 2017), as observed for C. xanthocarpa seedlings in the two irrigation suspension cycles although, abscission was observed only in the first irrigation suspension cycle.

We emphasize that our results in relation to leaf area were atypical because seedlings under II presented larger leaf area when compared to control seedlings. In general, in response to water stress and light due to excess of light, the species invests more energy in root production, which favors obtaining water in deeper layers of the soil with lower shoot growth. However, the C. xanthocarpa seedlings maintained the root growth in the shading of 30 and $70 \%$ and under II, similar to the control seedlings, however, showed higher leaf area growth.

This behavior suggests that this species by increasing the root system, it was able to increase water absorption and consequently of minerals and phytohormones, which favored the growth of shoots under water deficit (Jin et al., 2015). Associated with this behavior, osmotic adjustments occur with the production of organic acids such as malate and succinate, which are compounds responsible for important physiological functions in the plant, such as the participation in NADH reoxidation, glycolysis functioning, and formation of more ATP (Schachtman et al., 2008; Rocha et al., 2010), this favors water entry into the root system, so justifying the increase of the RWC of the shaded seedlings of C. xanthocarpa. It is noteworthy that from $2^{\text {nd }} \mathrm{P} 0$ until the END of the experiment (106 days), the seedlings when submissions to the second cycle of water deficit (II) presented a larger root system when compared to the control (CI). This behavior may be associated with stress memory, which are generated due to stressful conditions, debuting the storage of information that allows plants to become tolerant and respond immediately to stress (Bruce et al., 2007; Thellier and Lüttge, 2012)

The leaf area is an important variable that reflects adaptation to environmental changes and is related to growth, light interception, photosynthetic efficiency and perspiration (Fialho et al., 2011). This response mechanism found in C. xanthocarpa in moderate drought conditions provided by $30 \%$ shading, enabled the 


\section{2}

maintenance of RWC and stomatal opening with higher stomatic index when compared to its control (30\% $\mathrm{CI})$.

It is interesting to note that seedlings under water deficit under $30 \%$ shading despite having maintained the same leaf area and stomatic index had a higher stomatal opening than seedlings under $0 \%$. These stomatic responses show a strategy of C. xanthocarpa in maintaining the relative content of water in the leaves and signals the ability to adapt the species to the water deficit emphasizing our hypothesis that shading mitigated the effects of water restriction. When we consider the evaluation periods, we observed that the leaf area grows as a normal response of the species, however, this growth is significant in seedlings after going through the water deficit, which reflected in a stomatic index similar to that of control seedlings, suggesting that the increase in the leaf area was due to cell expansion and not to the increase in the number of cells. Thus, we also observed that the reduction of the stomatic index under lower luminous availability (70\%) is a consequence of the greater leaf expansion.

Correlating species of different families, which are common in forest formation, such as gallery forests (Cerrado Biome) and seasonal semideciduous forests (Atlantic Forest Biome) (Batista et al., 2014; Kelling et al., 2017), it was observed that in both phytophysiognomies shading minimized water deficit in the plants, as we found in $C$. xanthocarpa. Based on this information from native species in environments where $C$. xanthocarpa occurs, it can be inferred that leaf expansion is facilitated by increased shading (Alvarenga et al., 2003; Martins et al., 2014). We observed hypotheses in the literature justifying the behavior of plants in the face of stressful conditions, such as the facilitation hypothesis, which suggests that shading minimizes water deficit, especially among species tolerant to drought and shade. This behavior suggests that C. xanthocarpa presents plasticity that makes it possible to respond positively to facilitating interactions as observed in other species (Holmgren et al., 2012).

Considering the ecological aspects of $C$. xanthocarpa, which presents a late secondary growth pattern requiring shaded sites (Gandolfi et al., 1995; Silva et al., 2003), it is believed that this study corroborated the established ecological characteristics. This is possible to prove through physiological aspects measured of photosynthetic rates, the physiological plasticity of this species. Consequently, the results observed in this work allow us to disagree with our hypothesis that C. xanthocarpa seedlings are intolerant to water deficit since, although sensitive, showed potential for recovery or maintenance of photosynthetic and growth characteristics. However, we agree with the hypothesis that shading minimizes the stressful effects of water deficit. This specie likely presents physiological plasticity to water deficit and shading. The physiological aspects measured in this study may corroborate already established studies for successional classification of forest formation; these ecological characteristics have to date only been described visually by the researchers.

\section{Conclusions}

The 30 and $70 \%$ shading mitigated the stressful effect of water deficit intermittent on Campomanesia xanthocarpa seedlings. Although sensitive to water deficit, they show a potential for recovery of photosynthesis and growth characteristics under all cultivation conditions.

\section{Acknowledgements}

The authors like to thank Coordenação de Aperfeiçoamento de Pessoal de Nível Superior (CAPES) and Conselho Nacional de Desenvolvimento Científico e Tecnológico (CNPq - Brazil) for the financial support of this research. 


\section{Conflict of Interests}

The authors declare that there are no conflicts of interest related to this article.

\section{References}

Alvarenga AAD, Castro EMD, Junior Lima EC, Magalhães MM (2003). Effects of different light levels on the initial growth and photosynthesis of Croton urucurana Baill. in southeastern Brazil. Revista Árvore 27(1):53-57. http://dx.doi.org/10.1590/S0100-67622003000100007

Batista NA, Bianchini E, Carvalho ES, Pimenta JA (2014). Architecture of tree species of different strata developing in environments with the same light intensity in a semideciduous forest in southern Brazil. Acta Botânica Brasílica 28:3445. http://www.scielo.br/pdf/abb/v28n1/v28n1a04.pdf

Bento LF, Scalon SDPQ, Dresch DM, Pereira ZV (2016). Potential for recovery of Campomanesia xanthocarpa Mart. ex O. Berg seedlings from water deficit. African Journal Agricultural Research 11:2775-2785. bttp://dx.doi.org/10.5897/AJAR2016.11231

Bruce TJA, Matthes MC, Napier JA, Pickett JA (2007). Stressful "memories" of plants: Evidence and possible mechanisms. Plant Science 173:603-608.

Campelo DDH, Lacerda CF, Sousa JÁ, Correia D, Bezerra AME, Araújo JDM, Neves ALR (2015). Leaf gas exchange and efficiency of photosystem II in adult plants of six forest species as function of the water supply in the soil. Revista Árvore 39(5):973-983. http://dx.doi.org/10.1590/0100-67622015000500020

DosAnjos L, Oliva MA, Kuki KN, Mielke MS, Ventrella MC, Galvão MF, Pinto LRM (2015). Key leaf traits indicative of photosynthetic plasticity in tropical tree species. Trees 29:247-258. https://doi.org/10.1007/s00468-014-1110-2

Fan X, Hu H, Huang G, Huang F, Li Y, Palta J (2015). Soil inoculation with Burkholderia sp. LD-11 has positive effect on wateruse efficiency in inbred lines of maize. Plant Soil 390:337-349. https://doi.org/10.1007/s1 1104-015-2410-z

Favaretto VF, Martinez CA, Soriani HH, Furriel RPM (2011). Differential responses of antioxidant enzymes in pioneer and late-successional tropical tree species grown under sun and shade conditions. Environmental Experimental of Botany 70:20-28. https://doi.org/10.1016/j.envexpbot.2010.06.003

Ferreira DF (2010). Programa de análises estatísticas (Statistical Analysis Software) e planejamento de Experimentos - SISVAR 5.3. Lavras: UFLA. http://www.scielo.br/pdf/cagro/v35n6/a01v35n6.pdf

Flexas J, Barbour MM, Brendel O, Cabrera HM, Carriquí M, Díaz-Espejo A, ... Warren CR (2012). Mesophyll diffusion conductance to $\mathrm{CO}_{2}:$ an unappreciated central player in photosynthesis. Plant Science 193:70-84. https://doi.org/10.1016/j.plantsci.2012.05.009

Fialho GS, Dalvi LP, Dalvi NBC, Kuhlcamp KT, Efgen EM (2011). Prediction of the leaf area in zucchini fruit: a non-destructive, exact, simple, fast and practical method. Revista Brasileira de Agropecuária Sustentável 1:59-63.

Gandolfi S, Leitão Filho HF, Bezerra CL (1995). Floristic survey and succession of shrub and tree species of one mesophytic semideciduous forest in the Guarulhos Municipality, SP. Revista Brasileira de Biologia 55(4):753-767.

Holmgren M, Gomez-Aparicio L, Quero JL, Valladares F (2012). Non-linear effects of drought under shade: reconciling physiological and ecological models in plant communities. Oecologia 169:293-305. https://link.springer.com/article/10.1007/s00442-011-2196-5

Jin K, Shen J, Ashton RW, White RP, Dodd IC, Parry MA, Whalley WR (2015). Wheat root growth responses to horizontal stratification of fertilizer in a water-limited environment. Plant and Soil 386(1-2):77-88.

Junglos FS, Junglos MS, Dresch DM, Pereira NS, Kodama FFM, Scalon SP (2016). Recovery of the photosynthetic capacity of Campomanesia adamantium Myrtaceae) after water deficit. Brazilian Journal of Botany 39(2):541-546. http://dx.doi.org/10.1007/s40415-016-0275-x

Kelling MB, Araujo MM, León EB, Aimi SC, Turchetto F (2017). Regímenes de riego y dosis de polímero hidroretenedor sobre características morfológicas y fisiológicas de plantas de Cordia trichotoma. Bosque 38(1):123-131. http://dx.doi.org/10.4067/S0717-92002017000100013 
Klafke JZ, Silva MA, Paningasp TF, Belli KC, Oliveira MF, Barichello MM, ... Viecili PRN (2010) Effects of Campomanesia xanthocarpa on biochemical, hematological and oxidative stress parameters in hypercholesterolemic patients. Journal of Ethnopharmacology 127:299-305. http://dx.doi.org/\%2010.1007/s11104-014-2249-8

Luber J, Oliveira, MIU, Ferreira, MFS, Carrijo TT (2017). Flora of espírito saanto: Campomanesia (Myrtaceae). Rodriguésia 68(5):1767-1790. http://dx.doi.org/10.1590/2175-7860201768514

Martins MQ, Bregonci IDS, Marçal TDS, Coelho R, Colwell FDJ (2014). Seedling emergence of five varieties of citric rootstocks grown in environments with different levels of shading. Plant Science Today 1(3):131-139. bttp://dx.doi.org/10.14719/pst.2014.1.3.37

Pena-Rojas K, Donoso S, Pacheco C, Riquelme A, Gangas R, Guajardo A, Durán S (2018). Respuestas morfo-fisiológicas de plantas de Lithraea caustica (Anacardiaceae) sometidas a restricción hídrica controlada. Bosque 39(1):27-36. http://dx.doi.org/10.4067/S0717-92002018000100027

Queiroz CGS, Garcia QS, Lemos Filho JP (2002) Photosynthetic activity and membrane lipid peroxidation of aroeira-do-sertão plants under water stress and after rehydration. Brazilian Journal of Plant Physiology 14(1):59-63. http://dx.doi.org/10.1590/S1677-04202002000100008

Rocha M, Licausi F, Araújo WL, Nunes-Nesi A, Sodek L, Alisdair RF, Van Dongen JT (2010). Glycolysis and the tricarboxylic acid cycle are linked by alanine aminotransferase during hypoxia induced by water logging of Lotus japonicus. Plant Physiology 152(3):1501-1513. http://dx.doi.org/10.1104/pp.109.150045

Rosa DB, Scalon SP, Cremon T, Ceccon F, Dresch DM (2017). Gas exchange and antioxidant activity in seedlings of Copaifera langsdorffii Desf. under different water conditions. Annals Brazilian Academic Science 89(4):3039-3050. http://dx.doi.org/10.1590/0001-3765201720170499

Salisbury EJ (1927). On the causes and ecological significance of stomatal frequency, with special reference to the woodland. Philosophical Transactions of the Royal Society of London 216:1-65.

Schachtman DP, Goodger JQD (2008). Chemical root to shoot signaling under drought. Trends Plant Science 13(6):281-287. https://doi.org/10.1016/j.tplants.2008.04.003

Silva FD, Oliveira RVD, Santos Loureiro NR, Paula AD (2003). Floristic composition and ecological groups of species of a sub montane semideciduous forest stretch on São Geraldo farm, Viçosa, Minas Gerais. Revista Árvore 27(3):311-319. http://dx.doi.org/10.1590/S0100-67622003000300006

Soares-Silva LH, Kita KK, Chagas e Silva F (1998 Fitossociologia de um trecho de floresta de galeria no Parque Estadual Mata dos Godoy, Londrina, PR, Brasil. Boletim do Herbário Ezechias Paulo Heringer 3:46-62. http://revistas.jardimbotanico.ibict.br/index.php/Boletim/article/view/917756/200

Souza RF, Machado AS, Galvão F, Figueiredo Filho A (2017). Phytosociology of tree vegetation in Iguaçu national park. Ciência Florestal 27(3):853-869. https://periodicos.ufsm.br/cienciaflorestal/article/view/28635/pdf

Taiz L, Zeiger E, Møller I M, Murphy A (2017). Fisiologia e desenvolvimento vegetal. $6^{\text {th }}$ Ed. Porto Alegre, Artmed, pp 858.

Thellier M, Lüttge U (2012). Plant memory: a tentative model. Plant Biology 15:1-12.

Walter J, Nagy L, Hein R, Rascher U, Beierkuhnlein C, Willner E, Jentsch A (2011). Do plants remember drought? Hints towards a drought-memory ingrasses. Environmental and Experimental Botany 71:34-40.
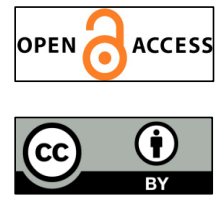

The journal offers free, immediate, and unrestricted access to peer-reviewed research and scholarly work. Users are allowed to read, download, copy, distribute, print, search, or link to the full texts of the articles, or use them for any other lawful purpose, without asking prior permission from the publisher or the author.

License - Papers published in Notulae Botanicae Horti Agrobotanici Cluj-Napoca are Open-Access, distributed under the terms and conditions of the Creative Commons Attribution (CC BY) License. (c) Articles by the authors; UASVM, Cluj-Napoca, Romania. The journal allows the author(s) to hold the copyright/to retain publishing rights without restriction. 